\title{
Understanding the Purchasing Behavior of Consumers in Response to Sustainable Marketing Practices: An Empirical Analysis in the Food Domain
}

\author{
Ilaria Mancuso ${ }^{1}$, Angelo Natalicchio ${ }^{1, *}$, Umberto Panniello ${ }^{1}$ and Paolo Roma ${ }^{2}$ \\ 1 Department of Mechanics, Mathematics, and Management, Politecnico di Bari, Via Orabona 4, \\ 70125 Bari, Italy; ilaria.mancuso@poliba.it (I.M.); umberto.panniello@poliba.it (U.P.) \\ 2 Department of Engineering, Università degli Studi di Palermo, Viale delle Scienze, 90128 Palermo, Italy; \\ paolo.roma@unipa.it \\ * Correspondence: angelo.natalicchio@poliba.it
}

Citation: Mancuso, I.; Natalicchio,

A.; Panniello, U.; Roma, P.

Understanding the Purchasing

Behavior of Consumers in Response to Sustainable Marketing Practices: An Empirical Analysis in the Food Domain. Sustainability 2021, 13, 6169. https://doi.org/10.3390/su13116169

Academic Editor: Francisco Guijarro

Received: 30 March 2021

Accepted: 25 May 2021

Published: 30 May 2021

Publisher's Note: MDPI stays neutral with regard to jurisdictional claims in published maps and institutional affiliations.

Copyright: (c) 2021 by the authors. Licensee MDPI, Basel, Switzerland. This article is an open access article distributed under the terms and conditions of the Creative Commons Attribution (CC BY) license (https:// creativecommons.org/licenses/by/ $4.0 /)$.

\begin{abstract}
Sustainability has become an important driver in defining business strategies, affecting most critical corporate functions and changing the way in which value is created, communicated, and distributed. This is increasingly impacting marketing practices, in particular, through promoting the development of sustainable marketing in the food sector. In line with this, our study aimed to investigate if and how sustainable marketing practices affect consumer loyalty to a specific brand. To answer our research questions, we relied on the results of a survey submitted to a sample of 907 Italian consumers of biscuits. Results showed that the consumers' attention to sustainable issues (in the absence of adequate information that can guide them in choosing a brand) did not result in brand loyalty. The same outcome was found when consumers were overloaded by marketing campaigns, which had the effect of confusing users and making them unfaithful. Ultimately, when consumers showed both engagement with sustainable concerns and sensitivity to marketing initiatives (i.e., they are sensitive to sustainable marketing practices), a positive effect on brand loyalty was observed. Our results contribute to the emerging stream of literature discussing the relevance and potential impact of sustainable marketing.
\end{abstract}

Keywords: consumer behavior; sustainability; sustainable marketing; food; brand loyalty

\section{Introduction}

Over the last few decades, significant interest and effort has been put into supporting sustainable economic development both from industrial and academic points of view [1,2]. The interest in adopting sustainable practices in industry has risen steadily since the publication of the Brundtland report in 1987, which clearly stated the need to pursue a model of "development that meets the needs of the present without compromising the ability of future generations to meet their own needs" [3]. Sustainability and sustainable consumption have been officially defined within The United Nations Environment Programme as "the use of services and related products that respond to basic needs and bring a better quality of life while minimizing the use of natural resources and toxic materials as well as the emissions of waste and pollutants over the life cycle so as not to jeopardize the needs of future generations" (https://www.unep.org/explore-topics/resource-efficiency/whatwe-do/sustainable-consumption-and-production-policies, accessed on 28 May 2021).

In parallel, the European Union has been working to implement sustainable development policies and, during the European Commission in 2008, presented the Sustainable Consumption and Production and Sustainable Industrial Policy Action Plan. That plan included a number of proposals to improve the environmental performance of products and the demand for more sustainable goods [4]. In this respect, the EU policies considered consumers "key stakeholders" in sustainable development processes and, thus, encouraged them to lead sustainable lifestyles [5]. 
Because of this, in recent years, firms have been embracing and communicating sustainable approaches. This, in turn, has attracted the interest of academics looking to spot effective trajectories of sustainable development. There are several examples that show the effort that firms have been devoting to following sustainable development approaches and reducing the environmental footprint of their operations. For instance, Amazon has adopted a broad, science-based approach to measuring, reducing, and eliminating carbon emissions in its operations. They have also promoted a more sustainable future by investing USD 2 billion to support the development of technologies and services that reduce carbon emissions and help preserve the natural world, including USD 100 million in reforestation projects and climate mitigation solutions (https://www.aboutamazon. $\mathrm{com} /$ sustainability, accessed on 28 May 2021). Another notable example is Ford. In recent years, the brand has increased its usage of renewable materials in vehicles, reduced its global waste by $5.5 \%$ (in 2018), and achieved a $14.5 \%$ reduction in water use since 2010 (https:/ /learn.g2.com/sustainability-in-business, accessed on 28 May 2021). IKEA has also been transforming its operations to embrace a circular economy approach. Moreover, its strategy has increasingly focused on designing smarter products using renewable or recycled materials, offering healthier and more sustainable food choices, and providing easier, more affordable ways for people to reduce their waste and use less (and cleaner) energy and water at home (https: / / www.ikea.com/gb / en/this-is-ikea/about-us/wereall-in-this-together-pubc8331c51, accessed on 28 May 2021).

It is, therefore, clear that sustainability issues are influencing the processes not only of companies and researchers, but also of the entire community, which has grown to be increasingly interested to the role of sustainability in daily contexts. In particular, the trend of consumers who are interested in social and environmental aspects connected to their purchasing processes has been shown to be constantly growing (https: / / www. ibm.com/downloads/cas/EXK4XKX8, accessed on 28 May 2021). The transformation of customers into aware and demanding buyers is now evident; these consumers punish companies that pay little attention to sustainability and reward companies that respect the environment and society (https:/ / www.accenture.com/us-en/insights/strategy/brandpurpose, accessed on 28 May 2021). Customers are also keen to recognize higher prices for products and services that come from firms who are committed to positive social and environmental impact (https:/ / www.nielsen.com/wp-content/uploads/sites/3/2019/0 4/nielsen-sustainability-workbook.pdf, accessed on 28 May 2021)

It has, therefore, become essential that companies integrate sustainability principles with strategic functions such as marketing, considering that the adoption and communication of sustainability practices has become a fundamental condition to establish or sustain competitive market advantage [6]. For this reason, companies and researchers have expressed growing interest in the role of sustainable marketing, convinced that it constitutes a corporate function with enormous strategic potential. Sustainable marketing plays a crucial role in operating and illustrating the steps and practices useful to obtain a sustainable business [7].

The current concept of sustainable marketing is a product of the evolution of the sustainability agenda in marketing over the last 30 years. When using the term sustainable marketing, we refer to marketing practices that fall within - and are supportive of-sustainable economic development [8]. Hence, sustainable marketing can be defined as "building and maintaining sustainable relationships with customers, the social environment and the natural environment" [9-11]. In other words, sustainability marketing tries to deliver increased value to customers by analyzing their needs and wants, developing appropriate sustainable solutions that are connected with the products and services offered, and promoting them effectively, leveraging their sustainability to target groups [11].

This attention to leverage on the marketing function for achieving and promoting sustainability goals is particularly relevant in the food domain. In fact, currently, consumers strongly influence the "business case" for sustainability [12,13]: they can respond to the company's action either positively by purchasing its products or, negatively, by 
boycotting its products [14,15]. EU citizens, especially in the food sector, have increased their awareness about the central role of the environmental issues in daily life decisions and choices, as the majority (slightly more than $80 \%$ ) believes that the impact of each product on the environment is an important element in deciding which products to buy, and almost $60 \%$ considered the environmental impact more important than the product's brand when making purchases [16].

These considerations have prompted many scholars to investigate the effects of sustainable practices on companies, businesses and society as a whole, and explore the practical mechanisms by which companies can act to be more sustainable [17], especially examining how the marketing function should evolve in order to embrace and communicate sustainable development values. Indeed, recent studies analyzed what regulates the decisionmaking process in purchasing sustainable foods and what level consumer knowledge is at regarding sustainability; this adds to the understand of how much expectations are affected and to what degree the extrinsic attributes of the food product influence perceptions of food quality [5,18-20].

However, to the best of our knowledge, few studies explored the purchasing behavior of consumers in relation to sustainable marketing practices. Therefore, our study aims to investigate if and how sustainable marketing practices affect consumer loyalty to a specific brand. In order to answer our research questions, we focused on the food industry and, specifically, marketing practices connected with biscuit purchases. Indeed, biscuits are a habitually purchased food product, consumed by a large number of consumers, thus, increasing the pool of interested users and the generalizability of our analysis. Accordingly, we set up a series of preliminary interviews by leveraging the Italian multichannel brand Al.ta Cucina, aiming to formulate a purposely developed survey that was subsequently administered to Al.ta Cucina users. Finally, our analysis is based on 907 biscuit consumers' answers to the survey.

Using this dataset, we have built a statistical model which we used to test three hypotheses, related to the study of the influence exerted by the consumers' interest in purchasing sustainable products and customers'sensitivity towards marketing practices on brand loyalty. In particular, we independently examined the effects that these two factors have on the dependent variable $(\mathrm{H} 1$ and $\mathrm{H} 2)$ and the joint effect that they exert on brand loyalty (H3). Our results show that the interest of consumers towards sustainability issues is negatively related to their loyalty to a brand, as well as the consumers' sensitivity to marketing practices. However, the interaction between these two consumer features positively affects the brand loyalty. In other words, consumers that are sensitive to sustainable marketing actions tend to focus their purchasing on a specific brand's product.

From a theoretical point of view, we contribute to the emerging stream of literature discussing the relevance and the potential impact of sustainable marketing practices (e.g., [8]). In fact, we delve further into this field, highlighting the need to inform consumers about the sustainability-related characteristics of the products to support their sustainable purchasing choices. In turn, this may enhance consumer brand loyalty. Furthermore, by investigating the consumers' sensitivity to sustainable marketing practices in the food sector, we shed light on the relevance of consumer behavior in relation with a sector characterized by the presence of customers eager for information about the sustainable features of the products.

Our results also provide practical implications. In particular, our results inform managers about the importance of effectively communicating the sustainability-related characteristics of products to potential consumers, in order to obtain stronger brand loyalty and, consequently, increased sales as a reward for sustainable business practices.

The rest of the paper is organized as follows: In Section 2, we review the extant literature on the role of sustainable marketing in informing the choices of consumers and we develop the hypotheses to be tested in the study. In Section 3, we present the methodology used in our study, while in Section 4, we show the main results obtained. Finally, in Section 5, we discuss the main implications and conclusions derived from this study. 


\section{Literature Review}

Sustainable marketing is rapidly becoming a central theme in the marketing literature. In fact, consumers substantially contribute to ecological and social problems both directly, in the form of emissions deriving from their consumption style, and indirectly, by demanding and paying for goods which cause problematic side effects along the value chain [21].

However, while the interest of scholars towards sustainable marketing has been growing in recent years, there is still a lack of consensus about the impact of consumer purchasing behavior on sustainable product (and service) sales. Indeed, some earlier studies pointed out that consumers adopt sustainable viewpoints to be socially accepted but may not follow through with sustainable behaviors [22]. In reality, green and ethical issues are a significant factor in consumer choices, influencing where they shop and what they buy $[23,24]$; however, these are not always the most dominant criteria for purchasing decisions [25]. In fact, the choice to buy sustainable products may be conditional upon the issues of price, convenience, accessibility, and perceived quality [26,27]. Recent research shows that $52 \%$ of consumers are interested in purchasing "earth-sustainable" foods, but do not purchase those foods because of the perceived barriers, e.g., a lack of availability, inconvenience, price, habit, and trust [28]. In addition, personal (e.g., low perceived consumer effectiveness, or ignorance of sustainable products) as well as contextual or situational (e.g., lack of sustainable products in local retail outlets) factors may inhibit the purchase of sustainable foods $[27,29]$.

Therefore, in this context, firms need to clearly communicate the sustainable practices adopted in order to improve the perception that consumers have of their products and increase the weight of sustainability as a purchase driver, eventually increasing consumer loyalty and, consequently, boosting sales.

For these reasons, an increasing number of food companies are experimenting with the use of marketing functions to amplify their efforts on sustainability issues. As an example, we can mention the cases of Barilla and Lavazza, two renowned Italian firms in the food industry, which have been revising their operations to embrace and communicate sustainable practices. On one hand, Barilla, one of the most famous Italian pasta producers, has been recently focusing on its environmental responsibility. In particular, they renewed the product packaging, which is now made of virgin fiberboard sourced from responsibly managed forests, according to certified standards (https: / www.esmmagazine.com/abrands/barilla-switches-100-italian-sustainable-wheat-98324, accessed on 28 May 2021). On the other hand, Lavazza has been very effective in communicating its sustainability values to its customers. Indeed, the Italian coffee manufacturer has recently launched the docu-film "Coffee Defenders, a Path from Coca to Coffee", inspired by the true story of a Colombian girl who managed to renovate her coffee farm during the armed conflict, promoting a story of female emancipation, in which a coffee plant becomes the symbol of rebirth. Based on this docu-film, Lavazza has launched an advergame with the aim of raising funds to support the communities of coffee farmers in Colombia. The video game allows the user to earn gems, each of which corresponds to EUR 0.01, thus helping to increase the sum that the Lavazza Foundation will send to Carcafè, a partner with whom it collaborates for a sustainable development project that has been underway for several years in support of small coffee producers in the area (https://www.lavazza.it/it/ sostenibilita/il-nostro-impegno/documentario-coffee-defenders.html, accessed on 28 May 2021). Furthermore, Lavazza promoted the "TOward2030. What are you doing?", an urban art initiative that has transformed the city of Turin into an amplifier of the 17 Sustainable Development Goals (SDGs) and that is the culmination of a series of proposals (including a children's book), spreading knowledge about SDGs among the youngest (https:/ /www. lavazza.it/it/landing/toward-2030.html, accessed on 28 May 2021). Finally, the 2020 edition of the Lavazza Calendar, entitled "Earth CelebraAction" and signed by the star of contemporary photography David LaChapelle, represented a tribute to the beauty of nature, full of reflections on the actions that everyone can take in defense of the environment (https:/ / calendar.lavazza.com/calendar-2020/project.html, accessed on 28 May 2021). 
In light of the examples just mentioned, it is evident how the use of marketing to communicate the sustainable goals achieved is becoming increasingly important. This new use of the corporate function strengthens the role more traditionally played by marketingnamely to inform potential consumers about food characteristics. In fact, consumers have great interest for direct indications of food quality [30], and their perceptions of product properties and product quality are significantly affected by information [31]. Hence, understanding how consumers behave in response to sustainable marketing actions may help us to understand how marketing campaigns could be effective from an environmental and wellbeing perspective and, concurrently, provide a reward in terms of sales for firms embracing sustainable approaches.

\subsection{Consumer Behavior in Response to Sustainable Marketing Actions}

The study of consumer behavior is defined as "those activities directly involved in obtaining, consuming, and disposing of products and services, including the decision processes that precedes and follows these actions" [32]. This discipline is strictly connected with marketing because it focuses on understanding several factors (e.g., demographics, personality, lifestyles, and loyalty) related to purchase decisions [33]. It is, therefore, clear that the study of consumers behavior plays a fundamental role in investigating the level of sensitivity towards sustainable marketing actions. Hence, in this section, we focus our attention on this topic, driven by the consideration that consumers are increasingly attracted by environmentally friendly products and have a positive attitude towards companies that offer these products and adopt sustainable practices (https:/ / www2.deloitte.com/uk/ en/pages / consumer-business / articles/sustainable-consumer.html, accessed on 28 May 2021). Moreover, studies also suggest that consumer involvement in choosing a green product relays on the growing environmental awareness among people, who realize that their purchase behavior influences environmental protection and concern [34,35].

On the one hand, if a growing interest in the purchase of sustainable products by virtue of a growing commitment to environmental and social issues is noted, on the other hand, it must be considered that green purchase behavior may be dependent upon different factors related to multiple perspectives. For instance, Rahman et al. [36] combined environmental (e.g., eco-friendliness and sustainability) economic (e.g., price and the affordability of switching costs) and psychological (e.g., trust, knowledge and self-image) factors in order to explain what conditions lead consumers towards green shopping. Zhang and Dong [37] reviewed a wide range of the literature on green purchase decision process, classifying the influencing factors into three categories: (i) individual factors (containing psychological factors such as attitude toward environment issues, awareness of green products, but also habits and socio-demographic factors such as education level, age, gender, occupation, family structure), (ii) product attributes and marketing (e.g., packaging, product price, eco-label, promotion, and e-advertisement), and (iii) social influence (e.g., social norm).

Many researchers have attempted to profile green consumers according to demographic variables; for instance, Peneda de Oliveira and Sousa [33] pointed out that young, high-income and educated woman are more likely to be interested in the sustainable aspect of the purchased products. In addition, Boztepe [38] found that young consumers are willing to pay a premium price for eco-friendly products. Moreover, his study proved that green promotion has a positive influence on purchasing behavior, highlighting the need for sustainable marketing to inform potential customers. This result is supported by Govender and Govender [39], whose survey showed that $76 \%$ of customers are motivated by advertisements to support the environment by purchasing green products. Therefore, it is important for companies to provide customers with clear information about their products and the corporate sustainability approaches adopted in order to favor green products' purchases. Specifically, organizations can adopt three different typologies of strategies of green advertising [40]: (i) addressing a relationship between a product/service and the biophysical environment, (ii) promoting a green lifestyle by highlighting a product or service, and (iii) presenting a corporate image of environmental responsibility. These 
advertisements can leverage different green marketing tools (e.g., eco-label, eco-brand, environmental awareness campaigns, green packaging), which aim to display product attributes, providing the consumers information regarding how it deals with environmental issues, and thus affecting their behavior.

\subsection{Consumer Behavior in Response to Sustainable Marketing Actions in the Food Domain}

The factors that generally influence consumers behavior regarding the purchase of green products (i.e., socio-demographic characteristics, personality, lifestyle, product attributes, safety concerns, environment, and health awareness) proved to be particularly relevant in the food sector [41-45].

Specifically, consumers are extremely interested in sustainability issues related to health, environmental care, and safety when purchasing foods. Considering this, a 2019 Altroconsumo survey on the relationship of Italians with sustainability in the food sector showed that $76 \%$ of respondents are concerned about the impact of their food expenditure on the environment and that $66 \%$ would like information on food sustainability to be mandatory (https: / / www.marketingjournal.it/buone-intenzioni-ma-poca-chiarezza-sullasostenibilita-alimentare-secondo-indagine-altroconsumo/, accessed on 28 May 2021).

Many researchers found that individuals with a higher level of sustainability, environmental concern and health awareness are more likely to consume green food products $[44,46,47]$. This consideration has prompted an increasing number of companies to communicate both a socially responsible image and greater information about the health benefits of green foods. As a result, consumer interest has been increased in response to corporate social responsibility (CSR) initiatives and green advertising carried out by food companies, shops, and restaurants [48-50]. In particular, the promotion of green practices and benefits is driven by several marketing communication channels. Alongside tools such as green branding and eco-labelling, the marketing actions of brands in the food domain focus on dynamizing workshops, social marketing initiatives, food trying and other events that spread the knowledge and educate the consumer, informing their decision making so they can act more consciously [33].

The impact of those advertising campaigns is amplified by word of mouth; this is a well-established marketing strategy even in the food sector. Indeed, Vassallo et al. [5] and Pandey and Khare [51] found social and peer influence to be a significant effect of on promoting the consumption of sustainable food products, supporting Tong and Wong [52], who believed that word of mouth plays a crucial role in communicating CSR initiatives in the food domain, influencing repeated purchases and positively perceived food quality.

Another widespread practice used for enhancing consumer loyalty is eco-labelling, a tool that an increasing number of companies are employing to communicate sustainable intentions and food health characteristics among customers. Sustainability labels provide consumers with information about compliance with standards relating to organic farming, with the local economy, animal welfare and the reduction in the environmental impact of production. The enormous value assumed by eco-labels as an effective marketing tool in the food sector has been investigated by Pelsmacker et al. [53] and, in more recent times, by Feucht and Zander [54]. Both these studies revealed that the sustainability label is one of the main factors that encourage buyers to prefer sustainable foods over conventional ones.

Often, the eco-labels are an integral part of packaging, one of the areas that most influences food choices. Packaging is a marketing action used not only to advertise a certain brand, but also to communicate to consumers an active commitment through environmental care. For instance, Rokka and Uusitalo [55] discovered that one third of consumers considered eco-friendly packaging as the most important driver among product attributes when buying a drink. This consideration is confirmed by recent studies: Magnier et al. [20], Hoek et al. [47] and Cecchele Lago et al. [56] found that sustainable packaging, which uses eco-friendly design and recycled materials, is a relevant attribute in green food purchase, especially among young consumers. The new generation, indeed, favors products and solutions that reduce the consumption of resources, waste, and environ- 
mental pollution, and this trend is reflected in food packaging choices. Moreover, this is one of the main results emerging from the "IBM Food Sustainability Study 2020" survey (https://www.ibm.com/easytools/runtime/hspx/prod/public/X0029/PortalX/filedocid/ f36e8d81ec8c4817a78b325362429c0d/MCIBMEuropeFoodSustainabilityStudyItalyReport.pdf, accessed on 28 May 2021), carried out by IBM and Morning Consult between the United States and Europe, which found that Italian GenZers (those born in the last 25 years) are the most excited group about reusable/refillable packaging and recyclable packaging.

Studying consumer behavior in response to definite sustainable marketing actions is a relevant topic from a scientific point of view, and much work has been done to elucidate this in the food domain. However, to the best of our knowledge, there is still a gap to explore regarding if and how sustainable marketing practices affect consumer loyalty to a specific brand.

\section{Hypotheses Development}

The sustainable marketing tools analyzed in the previous paragraph (green packaging, eco-labeling, advertising campaigns, and word of mouth) are indispensable because they provide and share relevant information about social, environmental, and ethical sustainability aspects. In this regard, companies are focusing on an important challenge, namely, the clear and effective communication of all the aspects and issues useful to spread a positive awareness on the benefits of sustainable food consumption [36,57,58].

This is a result of the growing demand from new food buyers to obtain the right amount of knowledge for a conscious purchase decision; indeed, according to Galati et al. [59], consumers who are aware of the social and environmental impact of their consumption choices pay more attention to the information displayed on the label. In general, several studies noticed consumers appreciate supplementary information about the certification of the production processes and the health, environmental and societal impact of products, and found that this information is essential in order to increase the willingness to pay and the satisfaction associated with the purchase of sustainable foods [60-65]. This is particularly true for young consumers, who are more sensitive towards aspects related to sustainable practices adopted during the production processes, which guide their preferences and purchase decisions $[56,66]$.

Therefore, based on the extant literature, in the following we discuss three hypotheses investigating the impact of sustainable marketing practices on consumer brand loyalty. The resulting descriptive model (Figure 1) aims to clarify the influence of the interest in sustainable products, the sensitivity towards marketing actions, and their interaction (i.e., sensitivity to sustainable marketing practices) on consumer brand loyalty, in the context of the food purchasing.

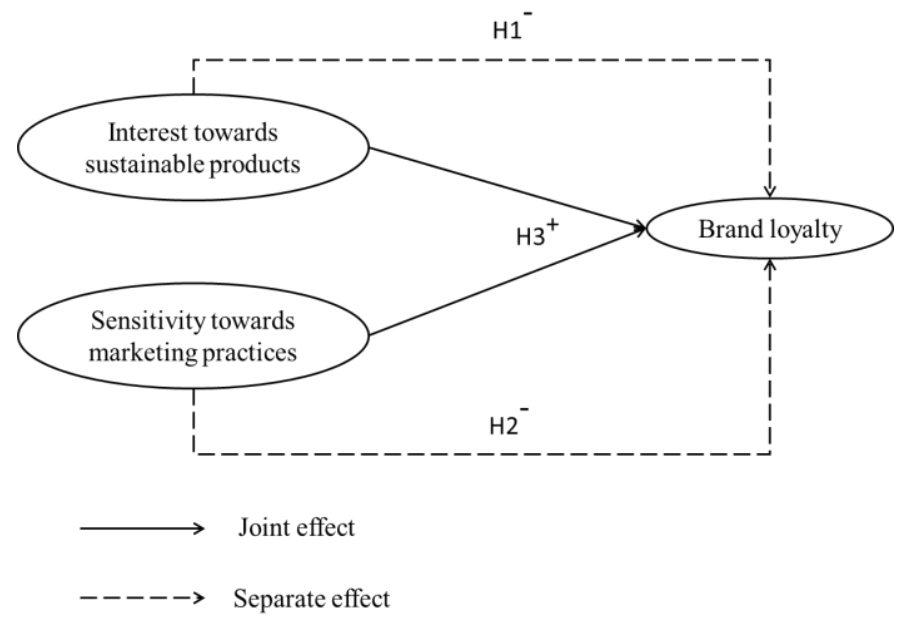

Figure 1. Conceptual model. 


\subsection{The Effect of the Interest of Consumers towards Sustainable Products}

The relationship between sustainable purchase and information was examined by several scholars, who agree that the lack of information and/or its complexity and its contradictory nature (e.g., about the need-satisfying capacity of the product, the benefits or the difference with respect to conventional production process) negatively influences green purchase behavior, because consumers feel less confident regarding which products to choose $[27,54,60,67,68]$. It should be noted that very often even though buyers perceive sustainable food products as healthy, safe, and of high quality, they are reluctant to buy them due to a lack of information on these products [19]. This result is consistent with the "IBM Food Sustainability Study 2020" report and the Altroconsumo survey, both of which agreeing that a lack of reliable food information holds Italian respondents back from eating greener products. In particular, according to Fernández-Serrano et al. [69], the major information gap about sustainability issues perceived by food customers is related to "production method", "percentage of the price received by farmers", "postharvest treatments", "sensory properties", "harvest date" and "environmental information", and, therefore, the industry should make efforts to provide this information or make it clearer than it currently is. Considering the newly revoked findings, we argue that due to contrasting and scant information, consumers interested in sustainable products may not have the level of knowledge required to choose a brand and, therefore, they try different products since they are not directed towards a sustainable one, thus reducing their loyalty towards a specific brand. Hence, we can pose the following hypothesis:

Hypothesis 1 (H1). The interest of consumers towards sustainable products is negatively related with their loyalty to a specific brand.

\subsection{The Effect of the Sensitivity of Consumers towards Marketing Practices}

The importance of clear information in supporting consumers in their conscious purchase decision has just been highlighted. However, if the lack of information has a negative effect on consumer loyalty towards a brand, the information overload (intended as the large proliferation of different labels on a same product or the presence of different sources of information which can sometimes be contradictory) also results in consumer confusion [70,71]. In addition, it must be considered the limits connected with the processing of this great amount of information, as related, for instance, to time pressure [72,73], which is one of the main reasons for simplifying the communication process. Based on those considerations, we hypothesize that consumers that are particularly sensitive to marketing practices, and they may be overly prone to collecting and processing information from different sources. The need to process various and contrasting information may lead consumers to be exposed to different stimuli and create confusion about a brand's characteristics. As a result, buyers may not prefer a single brand, but they choose several products according to the marketing practices they are exposed to. Consequently, their loyalty to a specific brand decreases. According to this reasoning, we can state the following hypothesis:

Hypothesis 2 (H2). The sensitivity of consumers towards marketing practices is negatively related with their loyalty to a specific brand.

\subsection{The Interaction Effect: Sustainable Marketing Practices}

Our third hypothesis regards the interaction between the consumer interest towards sustainability issues and their sensitivity to marketing practices. This entails consumers attentive to the information received through marketing practices, but specifically focusing on those related to the sustainable aspects of the products and services of interest. Indeed, consumers choose products based on the available information and, in the contest of sustainable food consumption, that information must make it possible to understand if the product actually satisfies both their needs and green issue. Considering this, Os- 
burg et al. [74] found that when eco-friendly product information is perceived as useful, purchase intention is positively affected, and this effect is intensified by an individual's environmental self-identity. Therefore, marketing tools such as advertisement may be helpful to allow buyers to make informed decisions about the products they consume and their impact on the environment, thus motivating them to support the environment through purchasing sustainable products [39]. Those considerations led us to suppose that consumers interested in sustainable practices may find the information they require to choose a product by relying on marketing practices. Moreover, if the information dispensed through marketing tools are available and oriented towards sustainability issues (i.e., when sustainable marketing practices are implemented), consumers can choose products satisfying their needs, thus being loyal to a specific brand. Therefore, our last hypothesis is as follows:

Hypothesis 3 (H3). The consumer interest towards sustainable products and their sensitivity to marketing practices have a positive interaction effect (i.e., sustainable marketing practices) on their loyalty to a specific brand.

\section{Methodology}

Our research goal is to study if and how sustainable marketing practices affect consumer loyalty to a specific brand. Therefore, we first conducted preliminary interviews involving a large number of consumers of food products in order to identify the main items to be included in a survey specifically developed to achieve our research objectives. In particular, the resulting survey was provided through the social pages of the well-known Italian multichannel brand Al.ta Cucina (https://altacucina.co/main, accessed on 28 May 2021). Al.ta Cucina started as a Facebook page where videos were used to explain how to replicate Italian recipes, through which users from all over the world could learn the secrets of Italian cuisine. Over the years, Al.ta Cucina has become very active on all the main social networks (Facebook, Instagram, and YouTube) with a community of almost 3 million and an average of 500,000 monthly interactions.

As previously mentioned, we decided to explore our research question in the food sector. We decided to focus on biscuits, since this is a food product which is habitually purchased and consumed by a large number of consumers, thus increasing the pool of users that could join our experiment and answer our survey.

We used the Al.ta Cucina Facebook page to carry out our research which has been articulated in three steps: (i) one-to-one interviews, (ii) interview analysis and, finally, (iii) formulation and administration of the survey.

The one-to-one interviews with consumers aimed to identify the items to be subsequently included into the survey. In particular, according to our research goal, we had to identify items which can be used to measure the users' sensitivity toward sustainable and marketing actions as well as the characteristics that they consider as more important when purchasing a product. For this, we conducted a number of interviews following the soft laddering methodology [75] with a representative set of users of the Al.ta Cucina Facebook group.

Data saturation was achieved after conducting in-depth interviews with 15 consumers over a three-week period, each interview lasting between 30 and 90 min. Data saturation refers to the point at which no new information or themes are observed in the data [76].

The interviews, conducted using the CAWI Methodology (Computer Assisted Web Interview), were transcribed, coded, and analyzed; in order to maximize the content and face validity of the items generated, we assessed the similarity of items, the clarity of phrasing and the terminology used in the scale [77].

All these activities were independently carried out by two researchers. A final number of 25 items was obtained and these were grouped into categories with respect to the subjects of the evaluation. All these items were turn in statements to be put in the final survey. As an example, sentences such as "the quantity of fat, artificial sweeteners additives and dyes 
used condition my purchase" were turned in statements such as "I am influenced by the ingredients used (i.e., additives, dyes, etc.) in the choice of the biscuit". For each statement we asked to the users to provide a rating on a Likert scale ranging from 1 to 7 (where 1 means "strongly disagree", 4 means "neutral" and 7 means "strongly agree"). In addition, we added four demographics (i.e., gender, age, family members and level of education) and four behavioral variables (i.e., what is the average price of the purchased packages, how many packages does the user usually consumed, what is the brand loyalty, does the user have intolerances) and three dummy consumption-related variables (what is the main occasion of use of cookies) to the survey thus reaching a final number of questions equal to 36. The statement used for the survey, the scale of measurement and the names of the variables are summarized in Table 1.

Table 1. List of variables used in the empirical analysis and measurements.

\begin{tabular}{|c|c|}
\hline Variable & Measurement \\
\hline BrandLoyalty & $\begin{array}{l}\text { Value 1: "I always buy different biscuits"; value 2: "I seldom buy the same biscuits"; value 3: "I } \\
\text { mainly buy the same biscuits"; value 4: "I always buy the same biscuits" }\end{array}$ \\
\hline Sustainability & I prefer recyclable packaging \\
\hline MarketingSensitivity & I am influenced by the advertising activity \\
\hline Crumbly & I prefer crumbly biscuits \\
\hline NutritionalValues & I am influenced by the nutritional values of biscuits \\
\hline Ingredients & I am influenced by the ingredients used \\
\hline Sweetness & I prefer not particularly sweet biscuits \\
\hline Chocolate & I prefer chocolate biscuits \\
\hline Stuffed & I prefer stuffed biscuits \\
\hline Flavor & I prefer biscuits with particular flavors \\
\hline Size & I prefer large biscuits \\
\hline Color & I prefer packaging with soft, pastel colors \\
\hline RealImages & I prefer packaging showing realistic images of the biscuits \\
\hline IngrImages & I prefer packaging showing images of the ingredients used \\
\hline SmallPack & I prefer small packs \\
\hline NutritionalInfo & I prefer that nutritional values are highlighted on the package \\
\hline IngredientInfo & I prefer that ingredients are highlighted on the package \\
\hline AdhesiveTap & I prefer packaging with an adhesive tab \\
\hline Transparent & I prefer packaging with transparent inserts \\
\hline NoPack & I prefer bulk biscuits \\
\hline SeparateShelv & I am attracted by biscuits displayed on separate shelves \\
\hline ColoredDisp & I am attracted by biscuits displayed on colored displays \\
\hline LowShelv & I am attracted by biscuits placed on the low shelves \\
\hline SocialCause & I am attracted by brands embracing social causes \\
\hline WoM & I am influenced by feedback coming from people I trust \\
\hline KnownBrand & I prefer to buy only brands I know \\
\hline Components & Number of family components (value 1: one; value 2: two; value 3: three; value 4: four or more) \\
\hline Price & $\begin{array}{l}\text { Price category of the biscuits typically bought (value EUR 1: 0-1.9; value EUR 2: 2-2.9; value 3: } \\
\qquad \text { EUR 3-4.9; value 4: more than EUR 5) }\end{array}$ \\
\hline Packages & $\begin{array}{l}\text { Average number of biscuit packs bought in a week (value 1: less than } 1 \text {; value } 2 \text { : one or two; } \\
\qquad \text { value } 3 \text { : three to five; value } 4: \text { more than five) }\end{array}$ \\
\hline
\end{tabular}


Table 1. Cont.

\begin{tabular}{cc}
\hline Variable & Measurement \\
\hline Intolerance & Dummy variable (value 1: I suffer from allergies or intolerance; value 0: otherwise) \\
\hline Breakfast & Dummy variable (value 1: I eat biscuits at breakfast; value 0: otherwise) \\
\hline Snack & Dummy variable (value 1: I eat biscuits as a snack; value 0: otherwise) \\
\hline Cake & Dummy variable (value 1: I use biscuits to make cakes; value 0: otherwise) \\
\hline
\end{tabular}

Where not specified users provided a rating on a Likert scale ranging from 1 to 7 (where 1 means "strongly disagree", 4 means "neutral" and 7 means "strongly agree").

The survey was provided via Al.ta Cucina Facebook page to reach Al.ta Cucina followers, obtaining an overall number of 1036 answers in $24 \mathrm{~h}$. In addition, through the Al.ta Cucina page, we could provide the survey to respondents who are particularly interested in food and food consumption, thus reaching a pool of potential respondents suitable for our research design. All the collected data were pre-processed in order to overcome inconsistency, incompleteness and noise issues. Finally, we spotted that 907 answers were complete and suitable for use in further analysis.

\subsection{Variables}

Dependent Variable. Our dependent variable (BrandLoyalty) is measured through the answers to a question related to the consumer loyalty to biscuit brands. In particular, the survey respondent could indicate if they always buy different biscuits (value 1), they seldom buy the same biscuits (value 2), they mainly buy the same biscuits (value 3), and they always buy the same biscuits (value 4). Of course, the higher the value of the variable, the higher the consumer's loyalty to a specific brand.

Independent Variables. The hypothesized relationships suggest the investigation of the effect of two different independent variables on the consumer's loyalty. The first independent variable (Sustainability) is measured through the answers to the item "I prefer recyclable packaging". Since this is not a specific feature of the biscuits, in this way we can assess the general interest and awareness of the consumers towards sustainable issues. In fact, it is reasonable to assume that consumers preferring recyclable packaging, that do not influence the taste of the product, are interested in reducing their environmental impact, by reducing the waste and the natural resource consumption. Moreover, the second independent variable (MarketingSensitivity) aims at measuring the consumer's sensitivity to marketing, through the item "I am influenced by the advertising activity". Indeed, this variable represents how much advertising campaigns can affect consumer choices; hence, it directly represents their sensitivity to marketing strategies.

Finally, we also interact with these two variables (Sustainability $x$ Marketing Sensitivity) by multiplying them, in order to understand their concurrent effect. In reality, assessing together the influence of consumer's interest toward sustainable practices and their sensitivity to marketing strategies may allow the relevance of sustainable marketing practices to be better understood, which is consistent with the aim of our research.

Control Variables. Along with the dependent and independent variables, our model also includes control variables, detailed in Table 1 . These take into account different features that may affect the main relationships to be investigated. In particular, eight variables control for consumer's preferences related to the biscuits (Crumbly, NutritionalValues, Ingredients, Sweetness, Chocolate, Stuffed, Flavor, Size), nine variables for packaging-related preferences (Color, RealImages, IngrImages, SmallPack, NutritionalInfo, IngredientInfo, AdhesiveTap, Transparent, NoPack), three variables for in-store positioning (SeparateShelv, ColoredDisp, LowShelv), and three variables for consumer's behavior influences (SocialCause, WoM, KnownBrand). Moreover, we also consider further control variables considering the number of consumer's family components (Components), typical price paid for biscuits (Price), average number of biscuits packages bought weekly (Packages), consumer's food intolerance (Intolerance). We also added three dummy variables for consumption preferences (Breakfast, Snack, Cake). 
Finally, the information collected about age, gender, and education level of the respondents were used to build 37 demographic clusters (Demograph). In particular, these clusters were built by identifying groups of customers whose age is within the same defined range and having the same gender and education level. Hence, we used the demographic questions to spot clusters of customers with similar characteristics and reduce potential biases in the analysis.

\subsection{Model Specification}

Our dependent variable (BrandLoyalty) is an ordinal variable, entailing an ordered response about the loyalty of consumers towards a specific brand. Hence, in this case, ordered logit regression and ordered probit regressions are particularly suitable [78]. In particular, to set up ordered regression models we can assume that $y^{*}$ is the latent dependent variable that is estimated by:

$$
y^{*}=\beta^{\prime} x+\varepsilon
$$

where $x$ is a vector of explanatory variables, $\beta$ is an unknown parameter vector, while $\varepsilon$ is the error term. Instead of the latent variable, with our survey approach we observe the ordinal values of the variable $y$ that refer to ranges of values that $y^{*}$ can assume. Hence:

$$
\begin{gathered}
y=1, \text { if } 0<y^{*} \leq \mu_{1} \\
y=2, \text { if } \mu_{1}<y^{*} \leq \mu_{2} \\
y=j, \text { if } \mu_{j-1} \leq y^{*}
\end{gathered}
$$

where $\mu$ is vector of threshold values for the latent variable.

Therefore, for the ordered logit model, the probability to observe the $i$-th outcome equal to $j$ is [79]:

$$
\operatorname{Pr}\left[y_{i}=j\right]=\frac{1}{1+e^{-\mu_{j}+\beta^{\prime} x_{i}}}-\frac{1}{1+e^{-\mu_{j-1}+\beta^{\prime} x_{i}}}
$$

and this probability can be used to estimate $\beta$ through the ordered logit regression. is [80]:

Differently, for the ordered probit model, the probability of observing the response $j$

$$
\operatorname{Pr}\left[y_{i}=j\right]=\Phi\left(\mu_{j}-\boldsymbol{\beta}^{\prime} x_{i}\right)-\Phi\left(\mu_{j-1}-\boldsymbol{\beta}^{\prime} x_{i}\right)
$$

where $\Phi(\cdot)$ is the standardized cumulative normal function.

In reality, in the following we show that using both models' results are consistent. Nonetheless, we focus our analysis on the ordered logit regression models, since they show lower values for both the Akaike Information Criteria (AIC) and the Bayesian Information Criteria (BIC), indicating a better fit $[81,82]$. Moreover, to account for potential correlations of errors connected with the demographic features of respondents, we ran our regression models using clustering across respondents' demographic features with robust standard errors [83]. In particular, we spotted 37 different clusters of respondents according to their

\begin{tabular}{|c|c|c|c|c|c|c|}
\hline Age & $\begin{array}{c}0-18: \\
30(3.31 \%)\end{array}$ & $\begin{array}{c}\text { 19-25: } \\
195(21.50 \%)\end{array}$ & $\begin{array}{c}\text { 26-35: } \\
233(25.69 \%)\end{array}$ & $\begin{array}{c}36-50: \\
287(31.64 \%)\end{array}$ & $\begin{array}{c}51-65: \\
152(16.76 \%)\end{array}$ & $\begin{array}{c}66+: \\
10(1.10 \%)\end{array}$ \\
\hline Gender & \multicolumn{3}{|c|}{$\begin{array}{c}\text { Male: } \\
92(10.14 \%)\end{array}$} & \multicolumn{3}{|c|}{$\begin{array}{c}\text { Female: } \\
815(89.86 \%)\end{array}$} \\
\hline $\begin{array}{l}\text { Level of } \\
\text { education }\end{array}$ & \multicolumn{2}{|c|}{$\begin{array}{l}\text { Middle School: } \\
100(11.03 \%)\end{array}$} & $\begin{array}{l}\text { High School: } \\
525(57.88 \%)\end{array}$ & \multicolumn{2}{|c|}{$\begin{array}{c}\text { Bachelor's Degree: } \\
156(17.20 \%)\end{array}$} & $\begin{array}{c}\text { Master's Degree: } \\
126(13.89 \%)\end{array}$ \\
\hline
\end{tabular}
age, gender, and level of education. Finally, for the purposes of our statistical analysis, we could rely on a subset of 907 complete surveys, out of the 1,036 responses collected. In Table 2, we report the characteristics of the respondents providing complete surveys, classified according to their demographic characteristics.

Table 2. Sample characteristics $(\mathrm{N}=907)$. 


\section{Results}

In Table 3, we report descriptive statistics and pairwise correlations among the variables. All the correlations are below the commonly accepted threshold of 0.70 [84]. Therefore, we can be confident that our results do not suffer of biases due to multicollinearity.

Table 3. Pairwise correlations and descriptive statistics.

\begin{tabular}{|c|c|c|c|c|c|c|c|c|c|c|c|c|c|c|c|c|c|}
\hline Variable & 1 & 2 & 3 & 4 & 5 & 6 & 7 & 8 & 9 & 10 & 11 & 12 & 13 & 14 & 15 & 16 & 17 \\
\hline \multicolumn{18}{|l|}{ 1. Brand Loyalty } \\
\hline 2. Sustainability & -0.009 & & & & & & & & & & & & & & & & \\
\hline $\begin{array}{l}\text { 3. Marketing } \\
\text { Sensitivity }\end{array}$ & $\begin{array}{l}0.053 \\
+\end{array}$ & -0.006 & & & & & & & & & & & & & & & \\
\hline 4. Crumbly & -0.052 & $\underset{*}{0.080}$ & 0.005 & & & & & & & & & & & & & & \\
\hline $\begin{array}{l}\text { 5. Nutritional } \\
\text { Values }\end{array}$ & $\underset{* *}{-0.096}$ & $\underset{* * *}{0.187}$ & -0.028 & $\underset{*}{0.072}$ & & & & & & & & & & & & & \\
\hline 6. Ingredients & $\underset{* *}{-0.093}$ & $\underset{* * *}{0.245}$ & $\underset{* * *}{-0.128}$ & $\underset{* *}{0.086}$ & $\underset{* * *}{0.571}$ & & & & & & & & & & & & \\
\hline 7. Sweetness & $\begin{array}{l}-0.068 \\
*\end{array}$ & $\underset{* * *}{0.202}$ & -0.139 & 0.102 & $\underset{* * *}{0.436}$ & $\underset{* * *}{0.457}$ & & & & & & & & & & & \\
\hline 8. Chocolate & 0.012 & $\underset{+}{0.061}$ & $\underset{* * *}{0.165}$ & $\stackrel{0.055}{+}$ & -0.018 & $\begin{array}{l}-0.072 \\
*\end{array}$ & $\underset{* *}{-0.081}$ & & & & & & & & & & \\
\hline 9. Stuffed & -0.019 & 0.022 & $\underset{* * *}{0.209}$ & 0.024 & $\underset{* * *}{-0.120}$ & $\underset{* * *}{-0.152}$ & $\underset{* * *}{-0.217}$ & $\underset{* * *}{0.470}$ & & & & & & & & & \\
\hline 10. Flavor & $\underset{* * *}{-0.112}$ & 0.041 & $\underset{* * *}{0.143}$ & 0.043 & -0.024 & 0.006 & $\begin{array}{l}-0.061 \\
+\end{array}$ & $\underset{* * *}{0.220}$ & $\underset{* * *}{0.466}$ & & & & & & & & \\
\hline 11. Size & $\begin{array}{l}-0.063 \\
+\end{array}$ & 0.049 & $\underset{* * *}{0.174}$ & -0.012 & 0.040 & -0.001 & -0.053 & $\underset{* * *}{0.147}$ & $\underset{* * *}{0.246}$ & $\underset{* * *}{0.380}$ & & & & & & & \\
\hline 12. Color & $\begin{array}{l}0.058 \\
+\end{array}$ & $\underset{* * *}{0.145}$ & $\underset{* * *}{0.187}$ & $\underset{* * *}{0.121}$ & 0.122 & $\underset{* *}{0.096}$ & 0.115 & $\underset{* *}{0.090}$ & $\underset{*}{0.064}$ & $\underset{* * *}{0.138}$ & $\underset{* * *}{0.171}$ & & & & & & \\
\hline 13. Real Images & 0.018 & $\underset{* * *}{0.245}$ & $\underset{* * *}{0.122}$ & $\begin{array}{c}0.139 \\
* * * \\
\end{array}$ & $\underset{* *}{0.088}$ & $\underset{* *}{0.090}$ & $\begin{array}{c}0.064 \\
+ \\
\end{array}$ & 0.038 & 0.054 & $\underset{* * *}{0.123}$ & $\underset{* *}{0.108}$ & $\underset{* * *}{0.412}$ & & & & & \\
\hline 14. Ingr Images & $\stackrel{-0.064}{+}$ & $\underset{* * *}{0.175}$ & 0.107 & $\underset{* * *}{0.147}$ & $\underset{* * *}{0.214}$ & $\underset{* * *}{0.214}$ & $\underset{* * *}{0.169}$ & 0.023 & 0.020 & $\underset{* *}{0.108}$ & $\underset{* *}{0.098}$ & $\underset{* * *}{0.246}$ & $\underset{* * *}{0.426}$ & & & & \\
\hline 15. Small Pack & 0.020 & $\underset{* * *}{0.164}$ & $\underset{* *}{0.078}$ & $\underset{* * *}{0.112}$ & $\underset{* * *}{0.148}$ & $\underset{* * *}{0.136}$ & $\underset{* * *}{0.182}$ & -0.033 & -0.006 & 0.028 & $\stackrel{-0.060}{+}$ & $\underset{* * *}{0.145}$ & $\underset{* * *}{0.127}$ & $\underset{* * *}{0.125}$ & & & \\
\hline 16. NutritionalInfo & $\underset{* * *}{-0.111}$ & $\underset{* * *}{0.258}$ & -0.051 & $\underset{* *}{0.095}$ & $\underset{* * *}{0.650}$ & $\underset{* * *}{0.578}$ & $\underset{* * *}{0.400}$ & -0.042 & -0.086 & 0.018 & 0.002 & $\underset{* * *}{0.119}$ & $\underset{* * *}{0.190}$ & $\underset{* * *}{0.299}$ & $\underset{* * *}{0.190}$ & & \\
\hline 17. Ingredient Info & $\underset{*}{-0.084}$ & $\underset{* * *}{0.267}$ & 0.015 & $\underset{* * *}{0.139}$ & $\underset{* * *}{0.451}$ & $\underset{* * *}{0.479}$ & $\underset{* * *}{0.318}$ & -0.021 & -0.035 & $\underset{*}{0.066}$ & $\stackrel{0.055}{+}$ & $\underset{* * *}{0.147}$ & $\underset{* * *}{0.250}$ & $\underset{* * *}{0.426}$ & $\underset{* * *}{0.140}$ & $\underset{* * *}{0.676}$ & \\
\hline 18. AdhesiveTap & 0.030 & $\underset{* * *}{0.159}$ & $\underset{* *}{0.094}$ & $\underset{* * *}{0.137}$ & $\underset{*}{0.077}$ & $\begin{array}{c}0.083 \\
*\end{array}$ & $\underset{*}{0.071}$ & 0.050 & $\begin{array}{c}0.079 \\
*\end{array}$ & $\underset{* * *}{0.122}$ & $\underset{* *}{0.092}$ & $\begin{array}{l}0.129 \\
* * *\end{array}$ & $\underset{* * *}{0.274}$ & $\underset{* * *}{0.230}$ & $\underset{* * *}{0.185}$ & $\underset{* * *}{0.154}$ & $\begin{array}{c}0.199 \\
* * *\end{array}$ \\
\hline 19. Transparent & $\begin{array}{l}-0.082 \\
* \\
\end{array}$ & $\underset{* *}{0.086}$ & $\begin{array}{c}0.077 \\
*\end{array}$ & $\underset{* *}{0.097}$ & $\underset{* * *}{0.110}$ & $\underset{* *}{0.107}$ & $\underset{* * *}{0.128}$ & 0.049 & $\underset{* * *}{0.151}$ & $\begin{array}{c}0.163 \\
* * * \\
\end{array}$ & $\underset{* * *}{0.151}$ & $\underset{* *}{0.098}$ & $\underset{* * *}{0.173}$ & $\begin{array}{c}0.203 \\
* * * \\
\end{array}$ & $\underset{* * *}{0.173}$ & $\underset{* * *}{0.192}$ & $\underset{* * *}{0.188}$ \\
\hline 20. NoPack & -0.018 & $\underset{* * *}{0.145}$ & $\underset{* *}{0.087}$ & -0.005 & $\begin{array}{c}0.098 \\
* *\end{array}$ & $\underset{* *}{0.092}$ & 0.011 & 0.044 & $\underset{* *}{0.091}$ & $\underset{* * *}{0.156}$ & $\underset{* * *}{0.177}$ & $\underset{* * *}{0.148}$ & 0.035 & 0.045 & $\begin{array}{c}0.108 \\
* *\end{array}$ & $\begin{array}{c}0.101 \\
* *\end{array}$ & 0.051 \\
\hline 21. SeparateShelv & -0.019 & $\underset{+}{0.057}$ & $\underset{* * *}{0.152}$ & $\underset{* *}{0.087}$ & 0.051 & -0.005 & -0.006 & $\underset{* * *}{0.111}$ & $\underset{* * *}{0.130}$ & $\underset{* * *}{0.157}$ & $\underset{* * *}{0.137}$ & $\underset{* * *}{0.186}$ & $\underset{* * *}{0.115}$ & $\underset{* * *}{0.189}$ & $\underset{* * *}{0.145}$ & 0.032 & $\underset{*}{0.056}$ \\
\hline 22. ColoredDisp & 0.032 & 0.043 & $\underset{* * *}{0.247}$ & $\underset{* *}{0.087}$ & -0.041 & $\underset{* *}{-0.103}$ & $\underset{*}{-0.085}$ & $\underset{* * *}{0.150}$ & $\underset{* * *}{0.189}$ & $\underset{* * *}{0.196}$ & $\underset{* * *}{0.229}$ & $\underset{* * *}{0.201}$ & $\underset{* * *}{0.158}$ & $\underset{* * *}{0.127}$ & $\underset{* * *}{0.122}$ & -0.026 & -0.048 \\
\hline 23. LowShelv & -0.032 & -0.04 & $\underset{* * *}{0.129}$ & 0.045 & 0.028 & -0.011 & 0.007 & 0.043 & $\underset{* * *}{0.123}$ & $\underset{* * *}{0.167}$ & $\underset{* * *}{0.211}$ & $\underset{* * *}{0.158}$ & $\underset{*}{0.084}$ & $\underset{* *}{0.101}$ & $\underset{* * *}{0.111}$ & 0.022 & 0.028 \\
\hline 24. SocialCause & 0.007 & $\underset{* * *}{0.316}$ & $\underset{* * *}{0.143}$ & $\underset{*}{0.081}$ & $\underset{* * *}{0.178}$ & $\underset{* * *}{0.158}$ & $\underbrace{0.115}_{* * *}$ & 0.050 & $\stackrel{0.056}{+}$ & $\begin{array}{c}0.079 \\
*\end{array}$ & $\underset{* *}{0.088}$ & $\underset{* * *}{0.184}$ & $\underset{* * *}{0.155}$ & $\underset{* * *}{0.164}$ & $\underset{* * *}{0.147}$ & $\underset{* * *}{0.228}$ & $\underset{* * *}{0.223}$ \\
\hline 25. WoM & 0.041 & $\underset{* * *}{0.134}$ & $\begin{array}{c}0.449 \\
* * * \\
\end{array}$ & 0.014 & $\underset{* *}{0.092}$ & 0.049 & 0.001 & $\underset{* *}{0.105}$ & $\underset{* *}{0.091}$ & $\underset{* * *}{0.134}$ & $\begin{array}{c}0.097 \\
* *\end{array}$ & $\begin{array}{c}0.183 \\
* * * \\
\end{array}$ & $\underset{* * *}{0.187}$ & $\begin{array}{c}0.147 \\
* * * \\
\end{array}$ & $\begin{array}{c}0.087 \\
* *\end{array}$ & $\begin{array}{c}0.078 \\
*\end{array}$ & $\begin{array}{c}0.147 \\
* * * \\
\end{array}$ \\
\hline 26. KnownBrand & $\underset{* * *}{0.143}$ & -0.012 & $\underset{* * *}{0.279}$ & 0.051 & 0.037 & -0.027 & $\underset{*}{0.067}$ & 0.050 & -0.019 & 0.010 & 0.001 & $\underset{*}{0.065}$ & 0.041 & $\underset{* * *}{0.164}$ & 0.053 & $\underset{+}{0.065}$ & 0.051 \\
\hline 27. Components & 0.029 & 0.022 & 0.023 & -0.039 & -0.039 & -0.007 & -0.028 & -0.037 & 0.052 & 0.013 & $\begin{array}{l}-0.062 \\
*\end{array}$ & -0.010 & -0.019 & 0.006 & -0.038 & -0.001 & -0.011 \\
\hline 28. Price & -0.008 & 0.008 & $\underset{*}{-0.069}$ & -0.010 & 0.047 & $\begin{array}{c}0.072 \\
*\end{array}$ & $\begin{array}{c}0.056 \\
+ \\
\end{array}$ & -0.027 & -0.049 & -0.050 & 0.008 & 0.022 & -0.022 & 0.031 & 0.006 & $\begin{array}{c}0.075 \\
*\end{array}$ & $\begin{array}{c}0.095 \\
* *\end{array}$ \\
\hline 29. Packages & 0.021 & -0.027 & $\begin{array}{c}0.076 \\
*\end{array}$ & -0.049 & -0.032 & -0.039 & $\begin{array}{l}-0.078 \\
*\end{array}$ & $\begin{array}{c}0.057 \\
+\end{array}$ & $\underset{* *}{0.094}$ & $\underset{* * *}{0.110}$ & 0.048 & $\begin{array}{c}0.077 \\
*\end{array}$ & 0.037 & $\begin{array}{l}0.085 \\
*\end{array}$ & -0.039 & -0.042 & 0.035 \\
\hline
\end{tabular}


Table 3. Cont.

\begin{tabular}{|c|c|c|c|c|c|c|c|c|c|c|c|c|c|c|c|c|c|}
\hline Variable & 1 & 2 & 3 & 4 & 5 & 6 & 7 & 8 & 9 & 10 & 11 & 12 & 13 & 14 & 15 & 16 & 17 \\
\hline 30. Intolerance & -0.013 & -0.010 & $\underset{* *}{-0.089}$ & 0.041 & $\underset{*}{0.081}$ & $\underset{* * *}{0.110}$ & 0.003 & 0.021 & $\begin{array}{l}-0.055 \\
+\end{array}$ & 0.007 & -0.033 & 0.010 & -0.008 & 0.023 & $\underset{*}{0.059}$ & $\underset{*}{0.076}$ & $\underset{* *}{0.096}$ \\
\hline 31. Breakfast & 0.011 & 0.015 & $\begin{array}{c}-0.058 \\
+\end{array}$ & -0.018 & 0.013 & $\underset{*}{0.074}$ & 0.041 & -0.035 & $\underset{* * *}{-0.118}$ & -0.040 & -0.022 & -0.026 & -0.027 & 0.013 & -0.046 & 0.009 & 0.042 \\
\hline 32. Snack & -0.023 & 0.020 & $\underset{* *}{0.094}$ & -0.021 & -0.011 & -0.045 & $\underset{* *}{-0.097}$ & $\underset{* * *}{0.120}$ & $\underset{* * *}{0.154}$ & $\underset{* * *}{0.118}$ & $\underset{*}{0.067}$ & $\underset{*}{0.076}$ & 0.047 & 0.023 & -0.044 & -0.033 & -0.028 \\
\hline 33. Cake & $\underset{* *}{-0.094}$ & 0.030 & -0.054 & $\begin{array}{c}0.074 \\
*\end{array}$ & 0.003 & 0.015 & 0.024 & -0.010 & 0.012 & $\underset{* *}{0.087}$ & -0.010 & -0.004 & $\begin{array}{c}0.060 \\
+\end{array}$ & 0.049 & 0.021 & 0.016 & -0.010 \\
\hline Min & 1 & 1 & 1 & 1 & 1 & 1 & 1 & 1 & 1 & 1 & 1 & 1 & 1 & 1 & 1 & 1 & 1 \\
\hline Max & 4 & 7 & 7 & 7 & 7 & 7 & 7 & 7 & 7 & 7 & 7 & 7 & 7 & 7 & 7 & 7 & 7 \\
\hline Mean & 2.696 & 5.938 & 3.455 & 5.222 & 4.845 & 5.320 & 5.342 & 4.549 & 3.624 & 3.650 & 3.644 & 3.964 & 5.616 & 4.648 & 4.228 & 5.248 & 5.442 \\
\hline St.Deviation & 0.844 & 1.530 & 1.705 & 1.561 & 2.115 & 1.991 & 1.663 & 1.912 & 1.917 & 1.940 & 1.693 & 1.785 & 1.647 & 1.771 & 1.665 & 1.858 & 1.689 \\
\hline Variable & 18 & 19 & 20 & 21 & 22 & 23 & 24 & 25 & 26 & 27 & 28 & 29 & 30 & \multicolumn{2}{|c|}{31} & 32 & 33 \\
\hline 19. Transparent & $\underset{* * *}{0.275}$ & & & & & & & & & & & & & & & & \\
\hline 20. NoPack & 0.016 & $\underset{* * *}{0.150}$ & & & & & & & & & & & & & & & \\
\hline 21. SeparateShelv & 0.109 & $\underset{* * *}{0.146}$ & $\underset{*}{0.078}$ & & & & & & & & & & & & & & \\
\hline 22. ColoredDisp & 0.155 & 0.108 & 0.123 & $\underset{* * *}{0.511}$ & & & & & & & & & & & & & \\
\hline 23. LowShelv & 0.026 & 0.031 & 0.116 & $\underset{* * *}{0.322}$ & 0.417 & & & & & & & & & & & & \\
\hline 24. SocialCause & $\underset{* * *}{0.147}$ & $\underset{*}{0.081}$ & $\underset{* * *}{0.224}$ & 0.100 & 0.131 & $\underset{* *}{0.094}$ & & & & & & & & & & & \\
\hline 25. WoM & $\underset{* * *}{0.128}$ & $\underset{* *}{0.105}$ & 0.161 & $\underset{* * *}{0.115}$ & 0.170 & $\underset{* *}{0.096}$ & $\underset{* * *}{0.312}$ & & & & & & & & & & \\
\hline 26. KnownBrand & $\underset{* * *}{0.118}$ & $\underset{* *}{0.088}$ & 0.005 & 0.049 & $\underset{*}{0.082}$ & 0.028 & $\underset{*}{0.076}$ & $\underset{* * *}{0.115}$ & & & & & & & & & \\
\hline 27. Components & 0.021 & -0.022 & $\underset{*}{-0.066}$ & -0.001 & -0.003 & -0.043 & 0.012 & $\underset{*}{-0.066}$ & -0.012 & & & & & & & & \\
\hline 28. Price & 0.023 & -0.001 & 0.015 & 0.027 & -0.018 & -0.024 & 0.031 & -0.038 & 0.048 & -0.007 & & & & & & & \\
\hline 29. Packages & 0.042 & 0.008 & -0.044 & 0.045 & $\underset{*}{0.081}$ & 0.051 & -0.008 & 0.009 & 0.037 & $\underset{*}{0.078}$ & $\begin{array}{c}0.056 \\
+\end{array}$ & & & & & & \\
\hline 30. Intolerance & 0.030 & $\underset{*}{0.059}$ & 0.008 & 0.013 & 0.001 & -0.023 & 0.010 & 0.027 & -0.025 & -0.007 & 0.013 & 0.031 & & & & & \\
\hline 31. Breakfast & 0.004 & -0.030 & $\begin{array}{l}-0.078 \\
*\end{array}$ & 0.005 & -0.020 & -0.024 & $\underset{*}{-0.071}$ & $\begin{array}{c}-0.078 \\
*\end{array}$ & 0.048 & -0.013 & -0.017 & -0.010 & 0.004 & & & & \\
\hline 32. Snack & -0.028 & -0.017 & $\underset{* *}{0.090}$ & 0.024 & $\underset{*}{0.085}$ & $\underset{*}{0.085}$ & $\begin{array}{c}0.059 \\
+\end{array}$ & $\underset{*}{0.075}$ & $\begin{array}{l}-0.066 \\
*\end{array}$ & 0.047 & $\underset{* *}{-0.092}$ & $\underset{* *}{0.102}$ & 0.034 & -0.3 & $* * *$ & & \\
\hline 33. Cake & 0.021 & $\underset{*}{0.072}$ & 0.048 & 0.011 & 0.007 & -0.028 & $\underset{* * *}{0.122}$ & 0.013 & $\begin{array}{l}-0.057 \\
+\end{array}$ & $\begin{array}{c}0.057 \\
+\end{array}$ & $\underset{*}{-0.082}$ & 0.001 & -0.001 & -0 & & -0.013 & \\
\hline Min & 1 & 1 & 1 & 1 & 1 & 1 & 1 & 1 & 1 & 1 & 1 & 1 & 0 & ( & & 0 & 0 \\
\hline Max & 7 & 7 & 7 & 7 & 7 & 7 & 7 & 7 & 7 & 4 & 4 & 5 & 1 & 1 & & 1 & 1 \\
\hline Mean & 5.791 & 4.421 & 3.228 & 3.515 & 3.448 & 2.647 & 4.530 & 4.213 & 4.302 & 3.173 & 2.108 & 1.577 & 0.147 & 0.8 & & 0.381 & 0.256 \\
\hline St.Deviation & 1.671 & 1.866 & 1.919 & 1.802 & 1.765 & 1.656 & 1.639 & 1.828 & 1.884 & 0.931 & 0.652 & 0.834 & 0.354 & 0.3 & & 0.486 & 0.437 \\
\hline
\end{tabular}

In Table 4, we show the results of the ordered logit regressions. In particular, Model 1 includes only the control variables, while in Model 2, we add the independent variables and the interaction effect. Moreover, we also report the results of the ordered probit regressions. Specifically, in Model 3, we report only the control variables, while Model 4 is the full model. Moreover, we point out that results are consistent across models, thus increasing the robustness of our findings. However, for the reasons previously mentioned, we use the results of the ordered logit regressions to test our hypotheses. 
Table 4. Ordered logit and probit regressions.

\begin{tabular}{|c|c|c|c|c|}
\hline $\begin{array}{c}\text { Dependent Variable: } \\
\text { BrandLoyalty }\end{array}$ & $\begin{array}{c}\text { Model } 1 \\
\text { Ordered Logit }\end{array}$ & $\begin{array}{c}\text { Model } 2 \\
\text { Ordered Logit }\end{array}$ & $\begin{array}{c}\text { Model } 3 \\
\text { Ordered Probit }\end{array}$ & $\begin{array}{c}\text { Model } 4 \\
\text { Ordered Probit }\end{array}$ \\
\hline Sustainability & & $-0.140+(0.085)$ & & $-0.086 *(0.043)$ \\
\hline MarketingSensitivity & & $-0.316 *(0.157)$ & & $-0.185 *(0.083)$ \\
\hline $\begin{array}{c}\text { Sustainability x } \\
\text { MarketingSensitivity }\end{array}$ & & $0.046 *(0.023)$ & & $0.028 *(0.012)$ \\
\hline Crumbly & $-0.052(0.052)$ & $-0.051(0.051)$ & $-0.028(0.028)$ & $-0.027(0.028)$ \\
\hline NutritionalValues & $-0.039(0.059)$ & $-0.033(0.061)$ & $-0.023(0.030)$ & $-0.020(0.030)$ \\
\hline Ingredients & $0.007(0.055)$ & $0.003(0.061)$ & $0.004(0.030)$ & $0.002(0.032)$ \\
\hline Sweetness & $-0.030(0.040)$ & $-0.040(0.037)$ & $-0.015(0.024)$ & $-0.020(0.021)$ \\
\hline Chocolate & $0.016(0.038)$ & $0.013(0.039)$ & $0.009(0.019)$ & $0.008(0.020)$ \\
\hline Stuffed & $0.014(0.055)$ & $0.019(0.056)$ & $0.009(0.028)$ & $0.011(0.028)$ \\
\hline Flavor & $-0.138^{* *}(0.041)$ & $-0.139 * * *(0.041)$ & $-0.081^{* * *}(0.023)$ & $-0.081^{* * *}(0.023)$ \\
\hline Size & $-0.037(0.048)$ & $-0.035(0.048)$ & $-0.015(0.026)$ & $-0.015(0.026)$ \\
\hline Color & $0.094 *(0.047)$ & $0.096 *(0.045)$ & $0.053 *(0.026)$ & $0.054 *(0.025)$ \\
\hline Reallmages & $0.056(0.063)$ & $0.062(0.064)$ & $0.023(0.032)$ & $0.027(0.032)$ \\
\hline IngrImages & $-0.094^{+}(0.053)$ & $-0.099+(0.054)$ & $-0.047^{+}(0.028)$ & $-0.051^{+}(0.028)$ \\
\hline SmallPack & $0.059(0.045)$ & $0.067(0.043)$ & $0.032(0.025)$ & $0.036(0.024)$ \\
\hline NutritionalInfo & $-0.094(0.072)$ & $-0.098(0.074)$ & $-0.051(0.036)$ & $-0.054(0.037)$ \\
\hline IngredientInfo & $0.004(0.065)$ & $0.001(0.066)$ & $0.005(0.036)$ & $0.003(0.036)$ \\
\hline AdhesiveTap & $0.070^{+}(0.043)$ & $0.068(0.043)$ & $0.040^{+}(0.022)$ & $0.040^{+}(0.022)$ \\
\hline Transparent & $-0.077 *(0.033)$ & $-0.077 *(0.033)$ & $-0.045^{* *}(0.017)$ & $-0.045^{* *}(0.017)$ \\
\hline NoPack & $0.001(0.043)$ & $-0.001(0.043)$ & $0.006(0.025)$ & $0.005(0.025)$ \\
\hline SeparateShelv & $-0.041(0.046)$ & $-0.040(0.047)$ & $-0.018(0.026)$ & $-0.018(0.027)$ \\
\hline ColoredDisp & $0.048(0.059)$ & $0.056(0.061)$ & $0.023(0.032)$ & $0.028(0.032)$ \\
\hline LowShelv & $-0.031(0.043)$ & $-0.036(0.042)$ & $-0.023(0.023)$ & $-0.026(0.023)$ \\
\hline SocialCause & $0.042(0.051)$ & $0.042(0.051)$ & $0.018(0.028)$ & $0.019(0.027)$ \\
\hline WoM & $0.007(0.042)$ & $0.024(0.043)$ & $0.005(0.024)$ & $0.014(0.025)$ \\
\hline KnownBrand & $0.200^{* * *}(0.039)$ & $0.212^{* * *}(0.042)$ & $0.104^{* * *}(0.020)$ & $0.111^{* * *}(0.022)$ \\
\hline Components & $0.067(0.088)$ & $0.069(0.085)$ & $0.031(0.050)$ & $0.031(0.049)$ \\
\hline Price & $-0.087(0.095)$ & $-0.099(0.097)$ & $-0.047(0.051)$ & $-0.055(0.052)$ \\
\hline Packages & $0.047(0.090)$ & $0.051(0.087)$ & $0.032(0.047)$ & $0.034(0.046)$ \\
\hline Intolerance & $0.044(0.276)$ & $0.005(0.277)$ & $0.020(0.153)$ & $0.002(0.150)$ \\
\hline Breakfast & $-0.028(0.245)$ & $-0.014(0.240)$ & $-0.041(0.141)$ & $-0.029(0.137)$ \\
\hline Snack & $-0.156(0.165)$ & $-0.164(0.164)$ & $-0.082(0.096)$ & $-0.085(0.094)$ \\
\hline Cake & $-0.393 *(0.193)$ & $-0.412 *(0.202)$ & $-0.218^{+}(0.123)$ & $-0.232+(0.129)$ \\
\hline $\begin{array}{l}\text { Number of } \\
\text { observations }\end{array}$ & 907 & 907 & 907 & 907 \\
\hline Pseudo R2 & 0.0478 & 0.0497 & 0.0456 & 0.0479 \\
\hline Log pseudlikelihood & -838.16 & -836.12 & -840.08 & -837.72 \\
\hline
\end{tabular}


Model 1 shows that customers' preference for packaging with soft colors $(\beta=0.094$, $p<0.05)$ and an adhesive tab $(\beta=0.070, p<0.10)$ and for known brands $(\beta=0.200$, $p<0.001)$ positively affects their brand loyalty. In fact, it is possible to think that products packaged with soft colors and a natural appearance result in the minds of consumers as more genuine than those characterized by bright, unnatural colors or with evident contrasts, which, in the context of the purchase of products such as biscuits, could be associated with sophistication in ingredients or use of artificial food coloring. In reality, according to marketing experts (https:/ / hartdesign.com/industry-news/food-packagingcolor-influences-consumer-behavior, accessed on 28 May 2021), soft shades are suitable for foods related to mature consumers (who, in general, tend to be more inclined to make repeated purchases), while bright palettes are instead exploited by brands to appeal to children (almost certainly to encourage impulse purchases). As for the presence of an adhesive label to close the pack of biscuits, our result is consistent with extant studies highlighting that, in general, the easy-open/resealable food packs increase the customer's satisfaction level [85] and, consequently, may affect their willingness to buy a specific brand's products. We can, therefore, argue that packaging equipped with an adhesive label can increase customer loyalty, of which customer satisfaction is an antecedent.

In addition, the purchase of products from brands whose history, philosophy or production approach is known generates an increase in loyalty by virtue of the trust that one has for the brand and also by virtue of the recognition towards the values embodied by the brand. Indeed, one of the main objectives of branding is to build identity and establish an emotional connection with audience, which results in loyalty [86].

Continuing the analysis provided by Model 1 , we note that consumers' preferences for packaging showing images of the ingredients used $(\beta=-0.094, p<0.10)$ and with transparent inserts $(\beta=-0.070, p<0.010)$, and for flavored biscuits $(\beta=-0.138, p<0.01)$, as well as the propensity to use biscuits to make cakes $(\beta=-0.393, p<0.05)$, have a negative influence on the consumers' brand loyalty.

Indeed, it could be assumed that showing images of ingredients on packages of foods such as biscuits (which, generally, are made up of common and basic elements such as flour, eggs, sugar and chocolate) could constitute a poor differentiator for interested consumers, lowering the distinctiveness of the product, with negative effects on loyalty. Similarly, in general, the possibility of showing the product through transparent inserts may not generate a clear distinction of the product. In fact, product such as cookies are typically made up of the same ingredients and take on the same physical form, resulting in a similar appearance. Furthermore, consumer interest in flavored biscuits may make them more prompt to try new products that belong to different brands, hence reducing their loyalty to a specific brand. Instead, the shopping of biscuits to be used as a base for other sweet preparations is a purchase connected to a casual and unrepeated event, such as that of preparing a cake. In those cases, biscuits are deemed as basic raw materials and rarely subject to assessments based on their brand, but rather to cost issues or recipe suggestions, hence reducing consumer brand loyalty.

In Model 2, we found statistical support for Hypothesis 1. In fact, the interest of consumers towards sustainability issues, as corroborated by the preference for recyclable packaging, has a significant negative effect on the brand loyalty $(\beta=-0.140, p<0.10)$, as for our Hypothesis 1. Thus, we found enough statistical evidence to affirm that consumers interested in sustainability issues tend to be less loyal to a specific brand. The reason behind this consideration can be recognized in the need, expressed by consumer interest in sustainability issues, to receive additional information about the social, environmental and economic aspects related to the purchase of the product or the support of the brand. In fact, by revealing certain needs-such as the comprehension of the purchase impact or the uptake of the sustainable actions linked to the production, consumption and disposal of the product - and in the absence of desired indications, buyers may find themself in a position of indecision, ultimately opting to occasionally choose different products $[27,54,60,67,68]$. 
Furthermore, Model 2 also provides statistical support for Hypothesis 2. Indeed, the coefficient of MarketingSensitivity is significant and in the direction suggested by our Hypothesis $2(\beta=-0.316, p<0.05)$. Therefore, also consumers that have a propensity to be influenced by marketing activities are less loyal to a specific brand, due to the information overload which they are subject to [70,71]. Indeed, we can confidently argue that when customers are sensitive towards marketing actions, the proliferation of labels, advertising and other brand-related information can create confusion, resulting in poor brand loyalty.

Finally, Hypothesis 3 is statistically supported. In fact, the interaction Sustainability $x$ MarketingSensitivity is significant and consistent with our Hypothesis $3(\beta=0.046, p<0.05)$. Hence, consumers that are sensitive to sustainable marketing practices tend to increase their loyalty to a specific brand. This happens because buyers can intercept the information on sustainability-related features; therefore, they are able to make a conscious and resolute choice $[39,74]$, rewarding the brand capable of communicating these aspects with repeated purchases and an increase in loyalty.

\section{Discussion and Conclusions}

The interest of consumers towards sustainable practices has been growing in the last decades, consistent with the increasing awareness about the need to address environmental and social issues, in order to avoid compromising the wellbeing of future generations. Therefore, firms are increasingly committed to the adoption and communication of sustainable approaches. In turn, this trend resulted in the development of sustainable marketing practices, according to which firms leverage the sustainability aspect when delivering value to customers and promoting their products and services [8,11]. This attention towards sustainable marketing is specifically relevant in the food sector [41-45], due to the higher attention consumers devote to health, environmental, and safety issues when purchasing food. Accordingly, in our study, we aimed to shed light on the actual relevance of sustainable marketing. In particular, we aimed to investigate if and how sustainable marketing practices affect consumer loyalty to a specific brand. In order to answer our research questions, we developed and deployed, through the web platform Al.ta Cucina, a survey on consumer behavior in relation with biscuits purchasing. Specifically, our empirical analysis is based on 907 answers to the survey.

Results show that the interest of consumers towards sustainable products negatively influence their brand loyalty. In reality, this could be understood considering that consumers interested in sustainable issues may need an adequate level of information to distinguish the characteristics of different products in relation with their environmental and social impact. When this information is lacking or not consistent with the consumers' needs, as in the case of firms not leveraging sustainable marketing practices, uncertainty may affect consumers that, in turn, may be less confident regarding the products to be acquired $[27,54,60,67,68]$. This entails consumers avoiding their buying being focused on a specific brand and trying different alternatives, hence reducing their brand loyalty.

Moreover, we also found that as consumers are more sensitive to marketing practices, as they may be exposed to an overload of information increasing their confusion on product features $[70,71]$. Hence, this may result in consumers choosing different products by relying on the massive amount of information they receive through marketing activities. Therefore, also in this case, they do not focus their purchasing on a specific brand, reducing their brand loyalty.

Nevertheless, our results suggest that when consumers are concurrently both interested in sustainable products and sensitive to marketing practices (i.e., when they are sensitive to sustainable marketing practices), their brand loyalty increases. We can understand this finding considering that this typology of consumers may select and focus on a portion of the information conveyed by marketing activities. Specifically, they may focus on that information linked with the sustainable aspects of the products [39]. Therefore, marketing practices may be relevant for consumers, allowing them to make informed choices regarding product purchasing. Eventually, by being more aware of different product char- 
acteristics, consumers may opt for the brand that better satisfies their needs, eventually increasing their brand loyalty.

\subsection{Theoretical Contributions}

From a theoretical point of view, our study contributes to the emerging stream of literature on sustainable marketing (e.g., [8]), by highlighting how the interest, per se, of consumers towards sustainable issues is not sufficient to increase their loyalty to a brand promoting sustainable products. Indeed, consumers need to be properly informed, via marketing practices, about the characteristics of the products, to make their informed choices. Therefore, we point out the relevance of the information conveyed by marketing practices to influence the consumers' sustainable purchasing choices, along with the more investigated insights on the relevance of socio-demographic characteristics of consumers [41-45]. Hence, we switch our focus on how firms should interact with interested consumers to support them in selecting sustainable products. Furthermore, by performing our analysis in the food sector, we add to the studies discussing the critical role of sustainable marketing in food purchasing. In reality, consumers in the food sector are particularly concerned with environmental, social, and health issues and need information on these aspects to buy products [19]. Hence, we highlight the impact of sustainable marketing on brand loyalty with reference to a sector characterized by the presence of consumers willing to be informed on the sustainable characteristics of products.

In addition, our findings also highlight the role of information, also conveyed by leveraging packaging, in marketing practices (e.g., $[87,88])$. Specifically, we show that firms should understand the information required by potential consumers and convey this information through packaging in order to increase their loyalty. This was revealed to be particularly relevant in sustainable marketing.

\subsection{Practical Contributions}

Our analysis also offers practical contributions and suggestions to managers involved in marketing activities, especially in the food sector. Indeed, by highlighting the relevance of sustainable marketing activities in the food sector to increase consumer brand loyalty, we suggest managers to perform such activities to inform potential customers about sustainability-related characteristics of the products. In reality, consumers are increasingly eager for sustainable products, while they may not receive adequate information to support their purchasing choice. Hence, by providing relevant information via sustainable marketing practices, firms may increase consumer loyalty towards their brands and, concurrently, obtain a reward in terms of sales for their sustainable practices. In particular, several sustainable marketing tools can be adopted to inform customers, such as eco-labelling, awareness campaigns, eco-packaging, as well as indicating the carbon footprint or providing an assessment of the environmental impact of the product's life cycle. Therefore, sustainable marketing offers the opportunity to tap into potential consumers that are particularly sensitive both to marketing practices and sustainable issues. In addition, effective sustainable marketing practices may also increase the loyalty of these consumers towards a specific brand, ensuring that a considerable stream of revenues are coming from a potentially expanding typology of consumers.

\subsection{Limitations and Further Research}

However, our study also has some limitations that can be addressed in further research. First, we based our analysis on data related to the food sector. Nonetheless, given the relevance of the food sector to investigate sustainable marketing practices, it may be possible that other sectors can testify for a different impact of sustainable marketing on consumer brand loyalty. Hence, future studies may extend our research to other contexts. Second, and related to this, our analysis relies on data collected through surveys provided to consumers registered on the Italian multichannel brand Al.ta Cucina. In particular, since cultural differences may influence consumer purchasing choice, future studies may 
perform an analysis collecting data from different countries. This would provide more generality to our findings. Finally, future studies may investigate in detail the effects of different sustainable marketing activities, in order to better understand most effective practices to increase consumer brand loyalty. This would be critical to enhance the sales of organizations embracing sustainable practices.

Author Contributions: Conceptualization, U.P. and P.R.; Methodology, A.N. and U.P.; Formal Analysis, A.N.; Data Curation, U.P.; Writing-Original Draft Preparation, I.M. and U.P.; WritingReview and Editing, I.M. and A.N.; Supervision, U.P. and P.R. All authors have read and agreed to the published version of the manuscript.

Funding: This research received no external funding.

Institutional Review Board Statement: Ethical review and approval were waived for this study, due to absence of sensitive data and to the processing of all personal information of the subjects involved in the study anonymously.

Informed Consent Statement: Informed consent was obtained from all subjects involved in the study.

Data Availability Statement: The data presented in this study are available on request from the corresponding author. The data are not publicly available due to privacy issues.

Conflicts of Interest: The authors declare no conflict of interest.

\section{References}

1. Barbier, E. The Concept of Sustainable Economic Development. Environ. Conserv. 1987, 14, 101-110. [CrossRef]

2. Azapagic, A.; Perdan, S. Indicators of Sustainable Development for Industry: A General Framework. Process Saf. Environ. 2000, 78, 243-261. [CrossRef]

3. World Commission on Environment and Development. Our Common Future: Report of the World Commission on Environment and Development; Oxford University Press: Oxford, UK, 1987.

4. Brunori, G.; Lari, A. Strategie per il consumo sostenibile: Dall'efficienza alla sufficienza. Agriregionieuropa 2012, 30, 40-44.

5. Vassallo, M.; Scalvedi, M.; Saba, A. Investigating psychosocial determinants in influencing sustainable food consumption in Italy. Int. J. Consum. Stud. 2016, 40, 422-434. [CrossRef]

6. Arseculeratne, D.; Yazdanifard, R. How Green Marketing Can Create a Sustainable Competitive Advantage for a Business. Int. Bus. Res. 2014, 7, 130-137. [CrossRef]

7. Danciu, V. The contribution of sustainable marketing to sustainable development. Manag. Mark. 2013, 8, 385-400.

8. Van Dam, Y.K.; Apeldoorn, P.A.C. Sustainable Marketing. J. Macromark. 1996, 16, 45-56. [CrossRef]

9. Belz, F.-M. Marketing in the age of development. In System Innovations for Sustainability 1: Perspectives on Radical Changes to Sustainable Consumption and Production; Tukker, A., Charter, M., Vezzoli, C., Stø, E., Andersen, M.M., Eds.; Routledge: New York, NY, USA, 2008; pp. 116-135.

10. Belz, F.-M.; Peattie, K. Sustainability Marketing: A Global Perspective; Wiley: Chichester, UK, 2009.

11. Belz, F.-M.; Schmidt-Riediger, B. Marketing Strategies in the Age of Sustainable Development: Evidence from the Food Industry. Bus. Strategy Environ. 2009, 19, 401-416. [CrossRef]

12. Dyllick, T.; Hockerts, K. Beyond the business case for corporate sustainability. Bus. Strategy Environ. 2002, 11, 130-141. [CrossRef]

13. Ionescu-Somers, A. The food and beverage industry. In The Business of Sustainability; Steger, U., Ed.; Palgrave Macmillan: New York, NY, USA, 2004; pp. 178-198.

14. Henriques, I.; Sadorsky, P. The Relationship between Environmental Commitment and Managerial Perceptions of Stakeholder Importance. Acad. Manag. J. 1999, 41, 89-99.

15. Porter, M.; Kramer, M. Strategy and society: The link between competitive advantage and corporate social responsibility. Harv. Bus. Rev. 2006, 84, 78-92.

16. Eurobarometer. Europeans' Attitudes towards the Issue of Sustainable Consumption and Production; European Commission: Brussels, Belgium, 2009.

17. Hunt, S.D. Sustainable marketing, equity, and economic growth: A resource-advantage, economic freedom approach. J. Acad. Mark. Sci. 2011, 39, 7-20. [CrossRef]

18. Vermeir, I.; Verbeke, W. Sustainable food consumption among young adults in Belgium: Theory of planned behaviour and the role of confidence and values. Ecol. Econ. 2008, 64, 542-553. [CrossRef]

19. Laureati, M.; Jabes, D.; Russo, V.; Pagliarini, E. Sustainability and organic production: How information influences consumer's expectation and preference for yogurt. Food Qual. Prefer. 2013, 30, 1-8. [CrossRef]

20. Magnier, L.; Schoormans, J.; Mugge, R. Judging a product by its cover: Packaging sustainability and perceptions of quality in food products. Food Qual. Prefer. 2016, 53, 132-142. [CrossRef]

21. Schrader, U.; Thøgersen, J. Putting Sustainable Consumption into Practice. J. Consum. Policy 2011, 34, 3-8. [CrossRef] 
22. Zinkhan, G.; Carlson, L. Green Advertising and the Reluctant Consumer. J. Advert. 1995, 24, 1-6. [CrossRef]

23. Grunert, S.C.; Juhl, H.J. Values, environmental attitudes, and buying of organic foods. J. Econ. Psychol. 1995, 16, 39-62. [CrossRef]

24. Manget, J.; Münnich, F.; Roche, C. Capturing the Green Advantage for Consumer Companies; Boston Consulting Group: Boston, MA, USA, 2009.

25. Boulstridge, E.; Carrigan, M. Do Consumers Really Care about Corporate Responsibility? Highlighting the Attitude-Behavior Gap. J. Commun. Manag. 2000, 4, 355-368. [CrossRef]

26. Weatherell, C.; Tregear, A.; Allinson, J. In search of the concerned consumer: UK public perceptions of food, farming and buying local. J. Rural Stud. 2003, 19, 233-244. [CrossRef]

27. Vermeir, I.; Verbeke, W. Sustainable food consumption: Exploring the consumer "attitude behavioural intention" gap. J. Agric. Environ. Ethics 2006, 19, 169-194. [CrossRef]

28. Robinson, R.; Smith, C. Psychosocial and demographic variables associated with consumer intention to purchase sustainable produced foods as defined by the Midwest Food Alliance. J. Nutr. Educ. Behav. 2002, 34, 316-325. [CrossRef]

29. Diamantapoulos, A.; Schlegelmilch, B.B.; Sinkovics, R.R.; Bohlen, G.M. Can socio-demographics still play a role in profiling green consumers? A review of the evidence and an empirical investigation. J. Bus. Res. 2003, 56, 465-480. [CrossRef]

30. Pieniak, Z.; Verbeke, W.; Vermeir, I.; Brunsø, K.; Olsen, S. Consumer Interest in Fish Information and Labelling. J. Int. Food Agribus. Mark. 2007, 19, 117-141. [CrossRef]

31. Verbeke, W.; Ward, R.W. Consumer interest in information cues denoting quality, traceability and origin: An application of ordered probit models to beef labels. Food Qual. Prefer. 2006, 17, 453-467. [CrossRef]

32. Engel, J.F.; Blackwell, R.D.; Miniard, P.W. Consumer Behavior, 8th ed.; Dryden Press: New York, NY, USA, 1995.

33. Peneda de Oliveira, C.; Sousa, B. Green Consumer Behavior and Its Implications on Brand Marketing Strategy. In Green Marketing as a Positive Driver toward Business Sustainability; Naidoo, V., Verma, R., Eds.; IGI Global: Hershey, PA, USA, 2019 ; pp. 69-95.

34. Hartmann, P.; Ibáñez, V.A. Green value added. Mark. Intell. Plan. 2006, 24, 673-680. [CrossRef]

35. Yue, B.; Sheng, G.; She, S.; Xu, J. Impact of Consumer Environmental Responsibility on Green Consumption Behavior in China: The Role of Environmental Concern and Price Sensitivity. Sustainability 2020, 12, 2074. [CrossRef]

36. Rahman, A.; Barua, A.; Hoque, R.; Zahir, R. Influence of Green Marketing on Consumer Behavior: A Realistic Study on Bangladesh. Glob. J. Manag. Bus. Res. 2017, 17, 9-16.

37. Zhang, X.; Dong, F. Why Do Consumers Make Green Purchase Decisions? Insights from a Systematic Review. Int. J. Environ. Res. Public Health 2020, 17, 6607. [CrossRef] [PubMed]

38. Boztepe, A. Green Marketing and Its Impact on Consumer Buying Behavior. Eur. J. Econ. Polit. Stud. 2012, 5, 5-21.

39. Govender, J.P.; Govender, T.L. The influence of green marketing on consumer purchase behavior. Environ. Econ. 2016, 7, 77-85. [CrossRef]

40. Bukhari, S.S. Green Marketing and its impact on consumer behavior. Eur. J. Bus. Manag. 2011, 3, 375-383.

41. Verain, M.; Bartels, J.; Dagevos, H.; Sijtsema, S.; Onwezen, M.; Antonides, G. Segments of sustainable food consumers: A literature review. Int. J. Consum. Stud. 2012, 36, 123-132. [CrossRef]

42. Van der Zanden, L.; Van Kleef, E.; De Wijk, R.; Van Trijp, H. Understanding heterogeneity among elderly consumers: An evaluation of segmentation approaches in the functional food market. Nutr. Res. Rev. 2014, 27, 159-171. [CrossRef]

43. Rana, J.; Paul, J. Consumer behavior and purchase intention for organic food: A review and research agenda. J. Retail. Consum. Serv. 2017, 38, 157-165. [CrossRef]

44. Stranieri, S.; Ricci, E.C.; Banterle, A. Convenience food with environmentally-sustainable attributes: A consumer perspective. Appetite 2017, 116, 11-20. [CrossRef] [PubMed]

45. Kamenidou, I.C.; Mamalis, S.A.; Pavlidis, S.; Bara, E.-Z.G. Segmenting the Generation Z Cohort University Students Based on Sustainable Food Consumption Behavior: A Preliminary Study. Sustainability 2019, 11, 837. [CrossRef]

46. Ranjbarshamsi, H.; Omidi Najafabadi, M.; Hosseini, S.J.F. Factors Influencing Consumers' Attitudes toward Organic Agricultural Products. J. Agric. Food Inform. 2016, 17, 110-119. [CrossRef]

47. Hoek, A.C.; Pearson, D.; James, S.W.; Lawrence, M.A.; Friel, S. Shrinking the food-print: A qualitative study into consumer perceptions, experiences and attitudes towards healthy and environmentally friendly food behaviors. Appetite 2017, 108, 117-131. [CrossRef] [PubMed]

48. Pivato, S.; Misani, N.; Tencati, A. The impact of corporate social responsibility on consumer trust: The case of organic food. Bus. Ethics 2008, 17, 3-12. [CrossRef]

49. Kim, E.; Ham, S. Restaurants' disclosure of nutritional information as a corporate social responsibility initiative: Customers' attitudinal and behavioral responses. Int. J. Hosp. Manag. 2016, 55, 96-106. [CrossRef]

50. Li, Y.; Biqiang, L.; Huan, T.C. Renewal or not? Consumer response to a renewed corporate social responsibility strategy: Evidence from the coffee shop industry. Tour. Manag. 2019, 72, 170-179. [CrossRef]

51. Pandey, S.; Khare, A. The Role of Retailer Trust and Word of Mouth in Buying Organic Foods in an Emerging Market. J. Food Prod. Mark. 2017, 23, 926-938. [CrossRef]

52. Tong, C.; Wong, A. The Influences of Corporate Social Responsibility to Customer Repurchases Intentions, Customer Word-ofMouth Intentions and Customer Perceived Food Quality of Fast-Food Restaurants in Hong Kong and the Mediating Effects of Corporate Reputation. Br. J. Econ. Manag. Trade 2014, 4, 1655-1678. [CrossRef] 
53. De Pelsmacker, P.; Driesen, L.; Rayp, G. Do consumers care about ethics? Willingness to pay for fair-trade coffee. J. Consum. Aff. 2005, 39, 363-385. [CrossRef]

54. Feucht, Y.; Zander, K. Consumers' preferences for carbon labels and the underlying reasoning. A mixed methods approach in 6 European countries. J. Clean. Prod. 2018, 178, 740-748. [CrossRef]

55. Rokka, J.; Uusitalo, L. Preference for green packaging in consumer product choices-Do consumers care? Int. J. Consum. Stud. 2008, 32, 516-525. [CrossRef]

56. Cecchele Lago, N.; Marcon, A.; Ribeiro, J.L.; Fleith de Medeiros, J.; Brião, V.; Antoni, V. Determinant attributes and the compensatory judgement rules applied by young consumers to purchase environmentally sustainable food products. Sustain. Prod. Consum. 2020, 23, 256-273. [CrossRef]

57. Bagdare, S. Marketing Communications for Sustainable Consumption: A Conceptual Framework. Int. J. Mark. Bus. Commun. 2018, 7, 45-49.

58. Marchini, A. Label information and consumer behaviour: Evidence on drinking milk sector. Agric. Food Econ. 2021, 9, 8. [CrossRef]

59. Galati, A.; Schifani, G.; Crescimanno, M.; Migliore, G. "Natural wine" consumers and interest in label information: An analysis of willingness to pay in a new Italian wine market segment. J. Clean. Prod. 2019, 227, 405-413. [CrossRef]

60. Padel, S.; Foster, C. Exploring the gap between attitudes and behaviour: Understanding why consumers buy or do not buy organic food. Br. Food J. 2005, 107, 606-625. [CrossRef]

61. Grunert, K.G.; Hieke, S.; Wills, J. Sustainability Labels on Food Products: Consumer Motivation, Understanding and Use. Food Policy 2014, 44, 177-189. [CrossRef]

62. Goucher-Lambert, K.; Cagan, J. The Impact of Sustainability on Consumer Preference Judgments of Product Attributes. J. Mech. Des. 2015, 137, 081401. [CrossRef]

63. Cerri, J.; Testa, F.; Rizzi, F. The more I care, the less I will listen to you: How information, environmental concern and ethical production influence consumers' attitudes and the purchasing of sustainable products. J. Clean. Prod. 2017, 175, 343-353. [CrossRef]

64. Emberger-Klein, A.; Menrad, K. The effect of information provision on supermarket consumers' use of and preferences for carbon labels in Germany. J. Clean. Prod. 2017, 172, 253-263. [CrossRef]

65. Aitken, R.; Watkins, L.; Williams, J.; Kean, A. The Positive Role of Labelling on Consumers' Perceived Behavioural Control and Intention to Purchase Organic Food. J. Clean. Prod. 2020, 255, 120334. [CrossRef]

66. Pomarici, E.; Vecchio, R. Millennial generation attitudes to sustainable wine: An exploratory study on Italian consumers. J. Clean Prod. 2014, 66, 537-545. [CrossRef]

67. Nagaraju, B.; Thejaswini, H.D. A study on consumer attitude towards eco-friendly FMCG products with reference to Hubli city in Karnataka. J. Bus. Manag. 2016, 18, 58-63.

68. Mtimet, N.; Souissi, A.; Mhamdi, N. Tunisian consumers perception and behavior towards organic food products. New Medit 2020, 19, 3-18. [CrossRef]

69. Fernández-Serrano, P.; Tarancón, P.; Besada, C. Consumer Information Needs and Sensory Label Design for Fresh Fruit Packaging. An Exploratory Study in Spain. Foods 2020, 10, 72.

70. Monier, S. Food labels: Consumer's information or consumer's confusion. OCL Oilseeds Fats Crop. Lipids 2018, 25, D202.

71. Rupprecht, C.; Fujiyoshi, L.; McGreevy, S.; Tayasu, I. Trust me? Consumer trust in expert information on food product labels. Food Chem. Toxicol. 2020, 137, 111170. [CrossRef]

72. Loebnitz, N.; Mueller Loose, S.; Grunert, K.G. Impacts of Situational Factors on Process Attribute Uses for Food Purchases. Food Qual. Prefer. 2015, 44, 84-91. [CrossRef]

73. Ankiel, M.; Sojkin, B.; Grzybowska-Brzezińska, M. Packaging as a Source of Information on the Product in Food Purchasing Decisions: The Case of Poland. Eur. Res. Stud. J. 2020, 23, 356-372. [CrossRef]

74. Osburg, V.S.; Yoganathan, V.; Brueckner, S.; Toporowski, W. How detailed product information strengthens eco-friendly consumption. Manag. Decis. 2019, 58, 1084-1099. [CrossRef]

75. Grunert, K.G.; Grunert, S.C. Measuring subjective meaning structures by the laddering method: Theoretical considerations and methodological problems. Int. J. Res. Mark. 1995, 12, 209-225. [CrossRef]

76. Glaser, B.G. Conceptualization: On Theory and Theorizing Using Grounded Theory. Int. J. Qual. Methods 2002, 1, 23-38. [CrossRef]

77. Klaus, P.; Gorgoglione, M.; Buonamassa, D.; Panniello, U.; Nguyen, B. Are you providing the "right" customer experience? The case of Banca Popolare di Bari. Int. J. Bank Mark. 2013, 31, 506-528. [CrossRef]

78. Wooldridge, J. Introductory Econometrics: A Modern Approach; Cengage Learning: Mason, OH, USA, 2012.

79. Sawkins, J.W.; Seaman, P.T.; Williams, C.S. Church attendance in Great Britain: An ordered logit approach. Appl. Econ. 1997, 29, 125-134. [CrossRef]

80. Abdel-Aty, M.A. Using ordered probit modeling to study the effect of ATIS on transit ridership. Transp. Res. Part C Emerg. Technol. 2001, 9, 265-277. [CrossRef]

81. Akaike, H. A new look at the Statistical Model Identification. IEEE Trans. Autom. Control 1974, 19, 716-723. [CrossRef]

82. Kass, R.E.; Raftery, A.E. Bayes factors. J. Am. Stat. Assoc. 1995, 90, 773-795. [CrossRef]

83. Cameron, A.C.; Trivedi, P.K. Microeconometrics Using Stata; Stata Press: College Station, TX, USA, 2000. 
84. Cohen, J.; Cohen, P.; West, S.G.; Aiken, L.S. Applied Multiple Regression/Correlation Analysis for the Behavioral Sciences; Erlbaum: Mahwah, NJ, USA, 2003.

85. Jinkarn, T.; Suwannaporn, P. Trade-off analysis of packaging attributes for food and drinks. Br. Food J. 2015, 117, 139-156. [CrossRef]

86. Mascarenhas, O.A.; Kesavan, R.; Bernacchi, M. Lasting customer loyalty: A total customer experience approach. J. Consum. Mark. 2006, 23, 397-405. [CrossRef]

87. Polonsky, M.J.; Bailey, J.; Baker, H.; Basche, C.; Jepson, C.; Neath, L. Communicating environmental information: Are marketing claims on packaging misleading? J. Bus. Ethics 1998, 17, 281-294. [CrossRef]

88. Wyrwa, J.; Barska, A. Packaging as a source of information about food products. Procedia Eng. 2017, 182, 770-779. [CrossRef] 